\title{
Balansując na krawędzi słowa: specyfika kobiecych świadectw obozowych (Delbo, Millu, Szmaglewska, Żywulska)
}

Początek wieku XXI to powrót zainteresowania polskich badaczy osobistymi relacjami byłych więźniów obozów koncentracyjnych. Mnożą się publikacje, których autorzy zastanawiają się głośno, w jaki sposób należałoby opowiadać o Zagładzie, jaką przyjąć formę, jaki dyskurs byłby dla jej zapisu odpowiedni ${ }^{\mathrm{I}}$. Wspomnienia obozowe traktowane są $\mathrm{w}$ tym kontekście jako specyficzna odmiana pisarstwa historycznego, oscylującego między prawdą historyczną a jej literackim zapisem² ${ }^{2}$. Wizje Holocaustu stają się coraz częściej przedmiotem rozważań nie tylko historyków, ale także - nawet zwłaszcza - literaturoznawców i socjologów. Wielu badaczy stawia sobie pytanie o granice przedstawiania tego wyjątkowego przeżycia, wobec którego funkcjonujące dotychczas metody i strategie językowe okazują się niewystarczające bądź po prostu nieużyteczne. Wciąż aktualna jest dyskusja sięgająca po teorie Hydena White' a czy Franka Ankersmita, a tocząca się wokół problemu przełożenia traumatycznych doświadczeń, jakimi są deportacja i pobyt w obozie. Od pewnego czasu zaobserwować można pewną prawidłowość, polegającą na oddzieleniu relacji kobiecych od świadectw męskich. Odpowiedź na pojawiające się wcześniej pytanie o to, jak opowiadać, zostaje więc poprzedzona pytaniem o społeczno-kulturową tożsamość płciową autora. Ta koncepcja, wpisująca się w gender studies, staje się - pomimo wielu krytycznych gło-

I Stosowność i forma. Jak opowiadać o Zagtadzie?, red. M. Głowiński, K. Chmielewska, K. Makaruk, A. Molisak, T. Żukowski, Kraków 2005; A. Ziębińska-Witek, Holocaust. Problemy przedstawiania, Lublin 2005; Holocaust w sieci dyskursów, red. A. Boroń, G. Gajewska, Gniezno 2005; A. Ubertowska, Świadectwo - Trauma - Głos. Literackie reprezentacje Holocaustu, Kraków 2007.

${ }^{2}$ Zob. B. Krupa, Wspomnienia obozowe jako specyficzna odmiana pisarstwa bistorycznego, Kraków 2006. 
sów - coraz bardziej popularna wśród badaczy holocaustowych narracji kobiecych ${ }^{3}$. Nie chodzi zatem o typowo feministyczne ujęcie tematu, pokazanie, w jakim stopniu los deportowanych i więzionych kobiet był lepszy czy gorszy od losu mężczyzn, lecz o to, jak odmienne jest kobiece postrzeganie rzeczywistości obozowej $-\mathrm{z}$ perspektywy uwarunkowań norm męskości i kobiecości obowiązujących w społeczeństwie. Jak wiadomo, świadkowie mężczyźni rzadko omawiają aspekty ściśle związane z konstrukcją kobiety i jej egzystencją w ekstremalnych warunkach. Obozowe ciąże, dramatyczne porody, przerwane macierzyństwo, eksperymenty naukowe, gwałty czy prostytucja - to tematy, do których odwołują się przede wszystkim kobiety ich bezpośrednie ofiary.

Przedmiotem moich rozważań będą cztery świadectwa kobiet, które przeżyły pobyt w Auschwitz-Birkenau: to Charlotte Delbo, Liana Millu, Seweryna Szmaglewska i Krystyna Żywulska - różnego pochodzenia (kolejno Francuzka, Włoszka i dwie Polki), wszystkie deportowane z powodu działalności w ruchu oporu, mimo że dwie z nich były żydówkami (Millu i Żywulska). Ich relacje są bardzo zróżnicowane i nie poddają się łatwo komparatystycznej analizie. Co prawda autorki pod wpływem podobnego impulsu biorą do ręki pióro, gotowe są opisać traumatyczne wspomnienie, jednakże obrana forma literacka - choć zawsze o charakterze czysto autobiograficznym - jest w każdym przypadku inna. Jedno zdaje się je łączyć: specyfika poruszanych (kobiecych) tematów oraz właściwa kobiecej naturze percepcja obozowej rzeczywistości, z którą się zmagają. Aby uchwycić ów aspekt, zastanówmy się najpierw nad statusem kobiecych narracji (począwszy od lat powojennych, ich charakterem i recepcją w danym kraju).

Do dziś niewiele jest publikacji, które zajmują się specyfiką relacji kobiet więźniarek ${ }^{4}$. Patrycja Bukalska w artykule Numery w kolorze lila ${ }^{5}$ podkreśla, że historia kobiet w obozach jest do tej pory zbadana fragmentarycznie. Powszechnie wiadomo, iż miały one mniejsze szanse przeżycia - już na rampie, przy wstępnej selekcji okazywały się po prostu zbyt słabe fizycznie, aby przedzielono je do komand roboczych. Matki z dziećmi z góry ska-

3 Zob. A. Nikliborc, Uwięzione w KL Auschwitz-Birkenau. Traumatyczne doświadczenia kobiet odzwierciedlone w dokumentach osobistych, Kraków 2010.

4 Tym bardziej godna uwagi jest wspomniana już publikacja A. Nikliborc. Sięgając po wybrane (polskie) świadectwa, autorka podkreśla wagę kobiecego punktu widzenia, analizuje złożone zachowania więźniarek oraz ich rolę w przekazywaniu traumatycznego doświadczenia.

5 P. Bukalska, Numery w kolorze lila, „Tygodnik Powszechny” 2009, nr 14. 
zane były na śmierć. Czynniki te spowodowały, że wśród osób, które przeżyły obóz, kobiety stanowiły tylko jedną trzecią.

Aby lepiej zrozumieć specyfikę osobistych relacji kobiet, należałby $\mathrm{z}$ pewnością powrócić do początków wieku XX i do roli, jaką zwykle odgrywały kobiety w czasie wojennej zawieruchy. Wojna jako taka z reguły pojawiała się zwykle w zapiskach mężczyzn uczestniczących w walce. We wspomnieniach powojennych czytamy nie tylko o cierpieniu, przemocy, ale przede wszystkim o heroicznej postawie walczących, ich odwadze i męstwie na polu bitwy. Pamięć o wojnie jest siłą rzeczy zmaskulinizowana, bo przecież kiedy mężczyźni walczą, większość kobiet stawia czoła trudnościom materialnym życia codziennego, cierpiąc z powodu rozłąki z najbliższymi czy ich śmierci. Kobiety, nawet jeśli są to pielęgniarki zaangażowane na polu bitwy (jak miało to miejsce w czasie I wojny światowej), nie są uważane za czynnych żołnierzy, a ich wspomnienia mają mniejsze znaczenie dla formowania pamięci kulturowej kraju. Wiąże się z tym nawet pewien mit: obraz kobiety we łzach, zrozpaczonej albo - wprost przeciwnie - dzielnej, czekającej na powrót męża, syna, brata. II wojna światowa odwraca tę perspektywę, zmienia istniejący dotychczas porządek. Jej konsekwencje nie godzą wyłącznie $\mathrm{w}$ zaangażowanych bezpośrednio $\mathrm{w}$ walkę, lecz powodują ogromne straty wśród ludności cywilnej, także kobiet i dzieci. Po raz pierwszy w dziejach ludzkości powrót z wojny „do domu” na tak dużą skalę dotyczy w równej mierze kobiet i mężczyzn, młodych i starych. Ma to oczywiście swoje odzwierciedlenie w literaturze. Po wojnie wiele kobiet decyduje się spisać swoje bolesne doświadczenia, co jest wówczas pewnym precedensem. O ile w Polsce komunistyczna propaganda eksploatuje obozowe wspomnienia, niezależnie od płci ich autorów (w podręcznikach i opracowaniach z zakresu historii literatury polskiej Tadeuszowi Borowskiemu wtórują zwykle Seweryna Szmaglewska, Zofia Kossak-Szczucka, rzadziej Krystyna Żywulska), o tyle we Francji czy we Włoszech problem jest bardziej złożony. Odnosi się nawet wrażenie, że świadectwa kobiet są początkowo marginalizowane i potrzeba czasu, by znalazły uznanie czytelników.

I tak na przykład Liana Millu - włoska żydówka, której $I l$ fumo di Birkenau (Dymy Birkenau) doczekały się niedawno tłumaczenia polskiego - publikuje swoje wspomnienia w 1947 r., ale $\mathrm{w}$ stosunkowo mało znanym wydawnictwie mediolańskim La Prora. Aby zrealizować swoje zamierzenie, potrzebuje między innymi wsparcia swego przyjaciela, współwięźnia - Prima Leviego, debiutującego zresztą $\mathrm{w}$ tym samym roku (Se questo è un uomo). To on jest autorem przedmowy, w której czytamy, 
iż książka Millu traktuje o „sprawach najbardziej kobiecych i rozpaczliwej walce więźniarek o przetrwanie" ${ }^{6}$. Levi uwypukla wielokrotnie fakt, że jest to świadectwo tyle przejmujące, co specyficzne, mówiące bowiem o różnej sytuacji kobiet i mężczyzn przebywających $\mathrm{w}$ obozie. Zdaniem autora przedmowy sytuacja kobiet była znacznie trudniejsza i wynikała nie tylko ze „słabszej wytrzymałości fizycznej przy robotach nieraz cięższych i bardziej upokarzających”, ale przede wszystkim z ,gorzej znoszonych dramatów rodzinnych" ${ }^{7}$. Levi ukazuje w ten sposób kobiece postrzeganie rzeczywistości obozowej jako warunkowane często wcześniejszymi doświadczeniami, uniemożliwiającymi przystosowanie się do panujących warunków, podkreśla znaczenie więzi emocjonalnych, łączących je $\mathrm{z}$ „normalnym światem”. W literaturze francuskiej niewątpliwie reprezentatywnym przykładem jest Charlotte Delbo, która czeka prawie 20 lat, zanim zdecyduje się na publikację swoich wspomnień Aucun de nous ne reviendra (1965), znanych czytelnikowi polskiemu pod tytułem Żaden z nas nie powróci ${ }^{8}$. Mimo że - jak w przypadku większości byłych więźniów - wspomnienia redagowane są bezpośrednio po odzyskaniu wolności, Delbo nie znajduje w sobie dość odwagi, by - jak twierdzi - ujrzały one światło dzienne. Oficjalnie argumentuje tę decyzję wymogami formalnymi i chęcią udoskonalenia wypowiedzi. Odnotować zresztą należy, że polskie tłumaczenia pierwszych tekstów Millu i Delbo są stosunkowo świeże (odpowiednio z 2007 i 2002 r.), podczas gdy pierwsze tłumaczenia Leviego pojawiają się już pod koniec lat 70. ubiegłego stulecia. Oczywiście można byłoby podać mnóstwo innych przykładów świadectw kobiecych, nieznanych czy kompletnie zapomnianych, jednak moim celem jest przede wszystkim ukazanie, a przynajmniej zasygnalizowanie, specyficznego wymiaru relacji, w których wizja obozowego świata przesiąknięta jest kobiecą wrażliwością.

Na wstępie zadajemy sobie zwykle pytanie, czy pamięć kobieca różni się od męskiej, a tym samym - czym różnią się wspomnienia mężczyzn od tych, których autorami są kobiety. Obok wielu elementów wspólnych - takich jak chęć dania świadectwa, będąca jednocześnie dla wielu byłych więźniów terapią, sposobem na odzyskanie równowagi psychicznej po przeżytej s. 5 .

${ }^{6}$ L. Millu, Dymy Birkenau, przeł. K. i E. Kabatcowie, Oświęcim 2007,

7 Ibidem.

${ }^{8}$ Ch. Delbo, Żaden z nas nie poreróci, przeł. K. Malczewska-Giovanetti, Oświęcim 2002. 
traumie ${ }^{9}$, uwolnieniem się od ciążącego obowiązku świadka, czyli tego, kto ma obowiązek moralny zaświadczyć - są także elementy charakterystyczne dla wspomnień kobiecych. Analiza wybranych świadectw, zarówno polskich, jak i francuskich oraz włoskich, pokazuje jednoznacznie, że w większości przypadków, niezależnie od przyjętej formy zapisu traumatycznego doświadczenia, autorki starają się wycofać siebie na drugi plan, skupiając uwagę na współwięźniarkach i wiernym opisywaniu rzeczywistości obozowej. Kobieca solidarność w przeżywaniu cierpienia narzuca "wielką dyskrecję wobec siebie”, jak to trafnie określił Kazimierz Wyka ${ }^{\mathrm{Io}}$, recenzując Dymy nad Birkenau Szmaglewskiej. „Jeżeli nawet przemówi w pierwszej osobie - kontynuuje Wyka - to jedynie wówczas, kiedy pragnie zaświadczyć o prawdziwości opisywanego a niezwykłego faktu. [...] Jako narrator jest po prostu jednym z więźniów" ${ }^{I I}$. Sama Szmaglewska wyznaje w jednym z wywiadów, że w początkowej fazie redakcji Dymów nad Birkenau posłuchała rady swojej znajomej - Antoniny Kłoskowskiej (później profesora socjologii) i zredukowała w rękopisie to „ja”, które było, jak sama później stwierdziła, zupełnie niepotrzebne ${ }^{\mathrm{I} 2}$.

Podobny rodzaj dyskrecji widoczny jest w relacji Millu. Nie nadużywa ona pierwszej osoby, oddając głos innym, których losy opowiada. Dymy Birkenau to sześć krótkich opowiadań, których autorka, choć znajduje się w centrum wydarzeń, zachowuje często dystans i skupia się na relacjonowaniu poszczególnych historii. Ich bohaterkami są zawsze kobiety, współwięźniarki, które zmuszone przez realia łagrowe podejmują często niełatwe decyzje przesądzające o ich życiu. Mówi o tym na przykład historia Marii: ukrywającej ciążę, zdecydowanej urodzić dziecko za wszelką cenę. Kobieta pozostawiona po porodzie z dzieckiem $\mathrm{w}$ brudnym baraku podczas porannego apelu wykrwawia się razem z nim na śmierć. Inna bohaterka, Bruna, również zmuszona jest wybrać. Kiedy w sąsiednim obozie odnajduje swojego syna, wycieńczonego i przeznaczonego do selekcji, rzuca się z nim na druty. Próbując go objąć, umiera $\mathrm{z}$ nim, porażona prądem. Za macierzyństwo płaci najwyższą cenę.

9 W sposób sugestywny mówił o tym chociażby P. Levi, który odczuwał nieodpartą potrzebę opowiedzenia o swoich przeżyciach właśnie po to, by się od nich wyzwolić: „Proces pisania, w moim przypadku, jest tym, czym podczas seansu psychoanalitycznego wyciagnięcie się na tapczanie”. F. Camon, Rozmowa z Primo Levim, Oświęcim 1997, s. 41-42.

то K. Wyka, Pogranicze powieści, Warszawa 1974, s. 79.

II Ibidem.

ז2 E. Sadowska [wywiad udzielony z okazji 70. urodzin Szmaglewskiej], „Kierunki” 1986, nr 12. 
Więzi rodzinne ulegają degradacji, co pokazuje historia dwóch holenderskich sióstr, z których jedna pragnie przeżyć i wybiera drogę ocalenia przez dom publiczny, a druga, poważnie chora, wyrzeka się jej, odrzucając pomoc bliskiej osoby.

Miłość okazuje się źródłem nieszczęść - Lily zostaje posłana na śmierć tylko dlatego, że kapo dostrzega w niej rywalkę. W innym opowiadaniu zakochana żona waha się: może pozostać wierna do końca swojemu mężowi i zginąć z głodu albo zdradzić go, by dla niego przetrwać. Poświęcenie widać w postawie Rosjanki, która pomaga jednemu z więźniów tylko dlatego, że przypomina on do złudzenia jej rozstrzelanego męża. Pomaga mu, ryzykując własne życie.

Delbo jest jeszcze bardziej powściągliwa. W celu zobiektywizowania relacji nie cytuje swojego imienia, używa jego pierwszej litery, podczas gdy współtowarzyszki noszą nie tylko imiona, ale i nazwiska. Zresztą Żaden znas nie powróci ma specyficzną formę, wymykającą się obowiązującym kanonom, oscylującą między prozą a poezją, określaną mianem prozy poetyckiej bądź poezji prozatorskiej - tak czy inaczej, z trudem mieści się w ramach klasycznych wspomnień obozowych zaliczanych zwykle do pro$\mathrm{zy}^{\mathrm{I}}$. W świadectwie Delbo ciekawe jest owo podwojenie własnej tożsamości, które przekłada się na dwa rodzaje pamięci - głębokiej (mémoire profonde) i zwykłej (mémoire ordinaire) ${ }^{\mathrm{I}}$. Pierwsza odnosi się do pogrzebanego w obozie „ja” autorki, natomiast druga jest jej poobozową konstrukcją, którą musi powołać do życia, by przeżyć w postłagrowej, czyli normalnej, rzeczywistości. Delbo pisze o tym, porównując swoją sytuację do stopniowego zrzucania skóry przez węża. Pogrzebane „ja” pozostaje w niej na zawsze, uaktywniając się od czasu do czasu jako psychiczny balast, niepozwalający normalnemu ,ja” w pełni nabrać dystansu do bolesnych doświadczeń ${ }^{15}$. Innymi słowy, można tu mówić o pewnym rozszczepieniu narracji holocaustowej ${ }^{16}$, prowadzącej do ukonstytuuowania się dwoistego podmiotu, w obrębie którego odzywają się głosy artykułujące treści z różnych warstw

I3 Pisze o tym m.in. B. Krupa, analizując formy wspomnień obozowych. Zob. B. Krupa, op.cit., s. 56.

${ }^{14}$ Zob. L.L. Langer, Holocaust Testimonies. The Ruins of Memory, New Haven-London 1991, s. 5. Notabene, ten amerykański historyk literatury wielokrotnie przywoływał świadectwo Delbo w swoich badaniach nad konwencją „pisania traumatycznego".

I5 Por. T. Łysak, Autobiografia (auto)biografii. „Maus” Arta Spiegelmana, w: Stosowność i forma..., s. 360.

I6 Temat ten porusza również S. DeKoven Ezrahi, Holocaust a zmieniające się granice sztuki i bistorii, przeł. M. Michalski, „Literatura na Świecie” 2004, nr $1-2$. 
doświadczenia ${ }^{17}$. Ma to niewątpliwie związek z przyjętą przez Delbo formą „pamięci ciała”, polegającą na kinestetycznym odwzorowaniu opisywanych zdarzeń. Można odnieść wrażenie, że osobista relacja filtrowana jest, a następnie przekazywana przez ciało, które zabiera głos. Umęczone, obolałe, zdeformowane, oszpecone. Spośród wielu fragmentów wspomnieć należałoby choćby ten, w którym podmiotem są stopy obserwowane podczas codziennego marszu:

Patrzysz ciagle na stopy stawiane przed siebie. Masz stopy idące do przodu, ciężko, idące przed siebie, stopy, które starasz się ominąć i których nigdy nie dogonisz, stopy idące przed tobą ciągle, nawet w koszmarze nocy, gdy się wzajemnie depczą [...], widzisz je, gdy ciągną się, potykają, idą. Idą, hałasując nierówno, rozregulowanym krokiem. A gdy idziesz za kimś, kto idzie boso, bo ukradziono jej buty, to widzisz bose stopy na lodzie lub w błocie, bose stopy w śniegu, wymęczone, których nie chcesz już widzieć, bo są żałosne i boisz się je nadepnąć, bo prześladują cię aż do mdłości ${ }^{18}$.

Przywołany cytat pokazuje jednocześnie, jak ważnym elementem w świadectwie Delbo są powtórzenia, w tym wypadku oddające nie tylko monotonię marszu, ale obrazujące bezsilność i beznadziejność obozowej egzystencji. Za pozorną prostotą dyskursu kryją się niewypowiedziane: cierpienie, strach, ból, głód i pragnienie. Opis marszu i wyglądu nóg wystarczą, by przedstawić warunki panujące w obozie.

Podobną, choć bardziej dyskretną wrażliwością emanują opowiadania Millu. Postrzeganie ciała, zmian, jakie w nim zachodzą, kolorów, lub nawet zapachów, pozwala nie tylko zobaczyć, ale i poczuć obóz, czy może raczej fosę, jaka oddziela przeszłość od teraźniejszości, tam od tu. Dzieje się tak, gdy jedna z więźniarek, Lily, otrzymuje od kapo polecenie naprawy rękawów podartego swetra. Narratorka, opisując scenę, nie może powstrzymać się od nostalgicznego komentarza, przepełnionego tęsknotą za normalnym życiem i potrzebą estetycznych doznań:

rozłożyła sobie na kolanach biały, miękki sweter. Przyglądała mu się z uwagą i musiała odczuwać przyjemność, dotykając rzeczy tak ładnej, przytulnej i ciepłej; jak sama to kiedyś odczuwałam (czy na-

${ }_{7}$ A. Ubertowska trafnie pisze o tym zabiegu narracyjnym jako „wewnętrznym dopełnianiu się wypowiedzi «ja» przeżywającego $i$ «ja» wspominającego", przywołując w tym kontekście dziecięcą narrację z Czarnych sezonów M. Głowińskiego. Zob. A. Ubertowska, op.cit., s. 97-100.

I8 Ch. Delbo, op.cit., s. 74-75. 
prawdę był kiedyś taki czas?), gdy zanurzałam twarz w miękki aksamit lub w bukiet kwiatów ${ }^{\text {I9 }}$.

W opowiadaniach Millu widać, że więźniarki są wrażliwe na otaczające je przedmioty, na ich estetykę. Jest to pewna prawidłowość pojawiająca się w świadectwach kobiecych. Kobiety, w przeciwieństwie do mężczyzn, starają się stworzyć w obozie namiastkę codzienności, wykonując podobne czynności, pamiętając o pozornie błahych szczegółach, takich jak przyszycie guzika, wypranie ubrania, czy nawet udekorowanie wnętrza baraku. W wybranych świadectwach znajdziemy odniesienie do świąt Bożego Narodzenia (nazywanego przez polskie autorki Gwiazdką) - pojawienie się małej choinki, wprowadzającej niezwykłą atmosferę, zawsze zostaje skrupulatnie odnotowane. U Millu dzieje się tak na przykład podczas święta Chanuka: szefowe bloku zamieszkałego w większości przez węgierskie żydówki „wstawiły tam stół przykryty bielutkim obrusem, ozdobiły wazonikami pełnymi polnych kwiatów, znoszonych przez komanda wiejskie swoim blokowym" ${ }^{20}$.

Skłonność do estetyzacji otoczenia przejawia się na różnych płaszczyznach. U Szmaglewskiej zaspokojeniem tej potrzeby okazuje się kontakt z przyrodą, która jest nie tylko źródłem pozytywnych doznań estetycznych, ale jednocześnie wyrazem tęsknoty za wolnością, powrotem do normalności. Dlatego praca poza obozem, na łonie natury, mimo że niepozbawiona negatywnej strony (wysiłek fizyczny, zmienne warunki atmosferyczne), jest często przedmiotem zazdrości i pożądania: „Las! Tęsknota do jego ciszy kojącej po straszliwym, nie milknącym gwarze lagru, tęsknota do chwili samotności [...]; tęsknota do trzasku gałęzi gnących się na wietrze, do cichego poświstu wilgi" ${ }^{21}$. Więzione kobiety, egzystujące w katastrofalnych warunkach sanitarnych i przechodzace kolejne etapy fizycznej degradacji ciała, przywiązują zaskakująco dużą wagę do wyglądu zewnętrznego. Niemal obsesyjnie powraca w wielu kobiecych świadectwach temat włosów. Utrata tego atrybutu kobiecości jest zawsze traumatycznym przeżyciem. Włosy, które się traci przy przyjęciu do obozu czy podczas choroby, bądź te, które odrastają i wzbudzają nierzadko zazdrość współwięźniarek. Włosy, ich obecność lub brak, stanowią niezmiennie o kondycji fizycznej, a także o pozycji zajmowanej w hierarchii obozowej. Wśród polskich autorek widać to między innymi w Przeżyłam

\footnotetext{
I9 L. Millu, op.cit., s. 23.

${ }^{20}$ Ibidem, s. 65.

${ }^{21}$ S. Szmaglewska, Dymy nad Birkenau, Warszawa 1989, s. 26.
} 
Ośweięcim Żywulskiej. Narratorka spostrzega szybko, że nowo przyjęte mają ogolone głowy, podczas gdy więźniarki „ze starymi numerami" mają włosy ${ }^{22}$. Proces golenia głów przebiega, według jej relacji, w milczeniu, kobiety unikają spojrzeń, nie chcą patrzeć na siebie wzajemnie, świadome, że wszystkie stają się do siebie podobne, że tracą własną tożsamość. "Nigdy nie sądziłam, wyznaje Krysia, że włosy nadają tyle indywidualności” ${ }^{23}$. W marzeniach sennych widzi siebie w słońcu, gdzieś nad morzem, z grzebieniem w ręku, rozczesującą swoje „długie włosy" ${ }^{24}$. Odrastające włosy są niejako powodem do dumy, nadzieją na zachowanie pozorów normalności. Kiedy narratorka Krysia po przejściu tyfusu opisuje swój „powrót do życia”, stwierdza: „Szum w uszach się zmniejszał. [...] Zaraz po apelu szłam do pracy. [...] Włosy zaczynały odrastać” ${ }^{25}$. W relacji Szmaglewskiej strzyżenie włosów czy „odwszawianie” wiążą się zarówno z poczuciem straty, jak i upokorzenia oraz towarzyszącego mu wstydu. Wymowna jest scena, w której autorka opisuje, jak kobiety zmuszone są rozebrać się do naga na oczach obecnych przy tym mężczyzn: „podejść do nich, pochylić głowę, żeby obejrzeli czy nie ma wszy, a potem wejść na stołek, podnieść ręce do góry i czekać na strzyżenia miejsc owłosionych" ${ }^{26}$. Wstyd przed nagością powraca i funkcjonuje inaczej niż w relacjach mężczyzn. Kobiety skłonne są zrobić wiele, cierpieć głód oraz fizyczny ból po to, by - pozostawiając na sobie podarte i brudne szczątki ubrania - chronić resztki swojej intymności i godności. Trzeba przy tym wspomnieć, że dbałość o higienę w okolicznościach braku podstawowych narzędzi służących do jej utrzymania również jest wątkiem obecnym we wspomnianych świadectwach. Więźniarki nawet w ekstremalnych warunkach kosztem snu organizują nielegalne miejsca kąpieli, np. wewnątrz spalonej częściowo komory gazowej, która staje się dla nich „najmilszą, zakonspirowaną łazienką”, gdzie z dala od spojrzeń esesmanów mogą umyć zmęczone i obolałe ciała ${ }^{27}$.

Innym elementem charakterystycznym dla kobiecych świadectw obozowych jest problem macierzyństwa w obozie. Bycie kobietą implikuje też $\mathrm{w}$ wielu przypadkach bycie matką. Millu przytacza wspomnianą już historię matki, która rzuca się z synem na druty kolczaste, czy też kobiety umierającej obok swoje-

\footnotetext{
${ }^{22}$ K. Żywulska, Przeżyłtam Oświęcim, Warszawa 2006, s. 17.

23 Ibidem, s. 18.

24 Ibidem, s. 47, 89.

25 Ibidem, s. 122.

${ }^{26}$ S. Szmaglewska, op.cit., s. 67.

27 Ibidem, s. 151.
} 
go nowo narodzonego dziecka. Szmaglewska i Żywulska opisują podobne przypadki. Ta ostatnia wspomina niemowlę greckiej żydówki, którego nie miał kto nakarmić, które „płakało, skomlało, słabło, puchło, wreszcie konało”. Wówczas, „wszyscy oddychali z ulgą" ${ }^{28}$. Komentarz narratorki pokazuje, jak trudnym doświadczeniem jest bezradność i niemoc wobec umierającego obok dziecka. Ciężarne kobiety robią jednak wszystko, aby utrzymać ciążę i urodzić dziecko, „lecz tylko po to, by je stracić” ${ }^{29}$. Mnożą się nie tylko przypadki oszalałych z bólu po stracie dziecka matek, ale i historie dzieci - w szoku, opuszczonych, czuwających przy zwłokach matki ${ }^{\circ}$. Kobiety matki mają często mniejsze szanse na przeżycie ${ }^{3}$. Odebranie kobiecie jej biologicznej funkcji - spełnienia się w roli matki - jest kolejnym aspektem degradacji moralnej i fizycznej człowieka.

O ile Millu, Szmaglewska i Żywulska również często poruszają te kwestie, o tyle Delbo czyni to w sposób powściągliwy, pozornie lakoniczny, o wiele bardziej wymowny. „Tutaj nie ma matek dla dzieci" ${ }^{2}$ - stwierdza po prostu, nie komentując ani nie wyjaśniając. Jej świadectwo zwraca uwagę brakiem chronologii zdarzeń typowej dla obozowych relacji osobistych, a wspomniana wcześniej wizualizacja doznań i uczuć powoduje, że podczas redakcji Delbo powraca wszystkimi zmysłami do pobytu w obozie i traumatycznych doświadczeń 33 . Nie mamy do czynienia z typową relacją w pierwszej osobie. „Ja” zastąpione zostaje przez „my”, a "my” oznacza kobiety, towarzyszki z francuskiego ruchu oporu, deportowane razem do AuschwitzBirkenau. Kobiety te wspierają się wzajemnie, walcząc o przetrwanie. „My” nie odnosi się nigdy do współwięźniów, Delbo nazywa ich mężczyznami, ponieważ w jej trylogii Auschwitz et après kobiety i mężczyźni należą do dwóch różnych światów, choć nie do końca od siebie odseparowanych. Ich równoległe - można by rzec - egzystencje splatają się niekiedy przypadkowymi spotkaniami, ukradkowymi spojrzeniami. Mężczyźni są jedynie obiektem spojrzeń kobiet: spojrzeń pełnych zrozumienia,

${ }_{28}^{8}$ K. Żywulska, op.cit., s. 107.

29 S. Szmaglewska, op.cit., s. 35.

3o Zob. K. Żywulska, op.cit., s. 194.

$3^{\text {I }}$ A. Nikliborc, opisując sytuację ciężarnych kobiet w obozie, wspomina o tym, jak poddawano je eksperymentom medycznym. Zob. A. Nikliborc, op.cit., s. 162-164.

${ }^{2}$ Ch. Delbo, op.cit., s. 25.

33 Delbo często podkreśla, jak ważnym aktem jest pisanie, jak wpływa na psychikę, jak odziera wręcz piszącego ze skóry, czyni go nagim, pozwala dotrzeć do najgłębszych pokładów wrażliwości „ja”. Zob. Ch. Delbo, Même l'bumoriste n'écrit pas pour s'amuser, „Le Monde”, 23 września 1981. 
a nawet litości. W spojrzeniu kryje się wielka czułość („grande tendresse"), o której wspomina Catherine Coquio ${ }^{34}$, i wszystkie niewypowiedziane słowa. W Żaden z nas nie powróci kobiety obserwujące maszerujących mężczyzn dają wyraz swojej bezsilności i bezradności wobec ich losu:

Było ich nam żal, bo musieli maszerować równym krokiem. My szłyśmy, każda jak mogła. [...] Na nogach mieli drewniaki pokryte płótnem, które nie trzymały się na nogach. Zastanawiałyśmy się, jak mogą maszerować w tych drewniakach. Idąc po śniegu lub lodzie, brali je w rękę. [...] W ich kościstych twarzach błyszczały oczy, podbite i z ciemną źrenicą. Usta mieli spuchnięte, czarne lub zbyt czerwone, i kiedy je rozchylali, widać było krwawe dziąsła. [...] Wyprostowani w marszu nie patrzyli na nas. My patrzyłyśmy na nich. Nasze dłonie zaciskały się z litości. Myśl o nich prześladowała nas, o ich marszu, o ich oczach ${ }^{35}$.

W relacji Delbo większość fragmentów organizuje się wokół tematu spojrzenia, kontaktu wzrokowego. Więźniarki wzajemnie nawołują się do tego, by patrzeć bądź - wprost przeciwnie nie patrzeć, gdy widok jest nie do zniesienia. W obozie jedna z pierwszych zasad brzmi: „nauczyć się patrzeć”, często paradoksalnie po to, by nie widzieć i aby inni nie uchwycili kierunku wzroku. Na początku pobytu w niewoli narratorka wyznaje : „Ja też patrzę. Patrzę na ruszającego się trupa i jest mi obojętny. Teraz jestem dorosła. Mogę patrzeć na nagie manekiny bez lęku" ${ }^{6}$. Jednak w miarę upływu czasu, kiedy następuje rodzaj oswajania obozowego świata, nasila się tendencja do odwracania wzroku. Nie tylko nie należy patrzeć na współwięźniarki („Przestaję patrzeć. Nie chcę na nią patrzeć. [...] Nie widzieć już tych dziur w oczach, dziur co przyciągają wzrok. [...] Odwracam głowę. Patrzeć gdzie indziej” ${ }^{37}$ ), ale nawet unikać patrzenia na siebie samą - wszystko po to, by przedłużyć nadzieję na przeżycie. Jeżeli jest ktoś, kto powinien patrzeć, to właśnie czytelnik, to on jest często nawoływany do oglądania przerażających scen. Wymowne są na przykład trzy następujące po sobie fragmenty, odpowiednio trzy różne obrazy - trupa, mężczyzny i kobiety, kończące się za każdym razem słowami długo dźwię-

34 C. Coquio, La tendresse d'Antigone. Charlotte Delbo, un témoignage au féminin, w: Témoigner entre bistoire et mémoire. Dossier Charlotte Delbo, red. Ph. Mesnard, Paris 2009, s. 146-147.

35 Ch. Delbo, Żaden z nas..., s. 36-37.

${ }^{36}$ Ibidem, s. 35.

37 Ibidem, s. 46. 
czącymi w uszach czytelnika: „Spróbujcie spojrzeć. Spróbujcie widzieć" ${ }^{8}$. W ten sposób autorka realizuje swoje podstawowe zamierzenie: zamiast opowiadać o obozowym świecie, stosując konwencjonalne zabiegi literackie - pozawala nam zobaczyć, poczuć go. Świadectwo Delbo to swoisty narracyjny nieporządek, wzmocniony fragmentarycznością i licznymi powtórzeniami. To tak, jakby podmiot wciąż doświadczał bezpośrednich efektów traumatycznego szoku. Forma ściśle przylega do treści, uzupełnia ją na swój sposób, pozwala odczuć czytelnikowi tragizm doświadczanej sytuacji. Fragment, wyrwa, wreszcie cisza, która zapada w tekście, są charakterystyczne dla Delbo, wyrażającej w ten sposób zarówno swoją ówczesną bezradność wobec rzeczywistości obozowej, jak i bezradność języka w momencie, kiedy autorka decyduje się ją wyrazić.

Zresztą Delbo nie jest osamotniona w tym odczuciu. Pozostałe autorki, o których była mowa, również zmagają się z formą, oswajają w pewnym sensie język, przystosowując go do opisu przeżytej traumy. Każda czyni to we właściwy sobie sposób: Millu preferuje krótkie opowiadania, w każdym zarysowuje jeden z „kobiecych” problemów, z kolei Szmaglewska i Żywulska decydują się na linearną narrację typową dla obozowych wspomnień - od momentu aresztowania aż do chwili, gdy „wokoło [...] nie ma drutów" ${ }^{39}$; obydwie autorki czują niezwykłą odpowiedzialność spoczywającą na świadku - wewnętrzny nakaz sprawia, że pragną, by wszyscy poznali prawdę o Auschwitz- Birkenau, by ludzie dowiedzieli się i zapamiętali. W ich relacjach często jest mowa o poczuciu obowiązku w dawaniu świadectwa: „to trzeba widzieć, żeby zapamiętać, żeby to sobie utrwalić w pamięci” ${ }^{\circ}{ }^{\circ}$ - czytamy, gdy narratorka wraz z innymi dziewczętami obserwuje jednego $\mathrm{z}$ esesmanów, który w masce przeciwgazowej i rękawiczkach wsypuje przez malutkie okienko biały proszek do „dziwnego budynku o czerwonych cegłach”, po czym rozlega się nieludzki jęk, który stopniowo słabnie, wreszcie milknie. Szmaglewska zaznacza już we wstępie do książki, że zamierza podać „fakty, bezpośrednio zaobserwowane albo przeżyte", zabierając głos w imieniu tych, którzy powrócili, lecz - jak podkreśla na koniec - „większość nie wróci nigdy

$3^{8}$ W thumaczeniu zaproponowanym przez K. Malczewską-Giovanetti, użyty czasownik „widzieć” zdaje się nie w pełni oddawać niuans słów Delbo, która pisząc „Essayez de regarder. Essayez pour voir”, uwypukla związek między patrzeniem a próbą zrozumienia obozowej egzystencji, tak odległej dla czytelnika (patrzeć po to, by zobaczyć, a zatem zrozumieć). Por. ibidem, s. 138-140.

39 K. Żywulska, op.cit., s. 310.

$4^{\circ}$ Ibidem, s. 163. 
i nigdy nie przemówi” ${ }^{\mathrm{I}}$. Tytułowe stwierdzenie Delbo: „Żaden $\mathrm{z}$ nas nie powróci" rozbrzmiewa $\mathrm{w}$ tym kontekście ze zdwojoną siłą. Francuska pisarka wręcz czuje się winna wobec tych, którzy nie powrócili, bo przecież „żaden z nas nie powinien był powrócić" ${ }^{2}$. Z czterech omawianych relacji jedynie świadectwo Żywulskiej tchnie nadzieją i wiarą: wyznanie „Przeżyłam Oświęcim” ze strony tytułowej prowadzi nas aż do przepojonego radością i szczęściem okrzyku: „Jestem wolna! Będę żyła!”43. Pozostałe autorki, zwłaszcza Delbo i Millu, opisują swoje doświadczenie tak, jakby obóz wciąż w nich tkwił, a granica kolczastych drutów nie została nigdy przekroczona.

\section{JOANNA TEKLIK}

\section{Balancing on the edge of word: specificity of women's accounts of concentration camp life (Delbo, Millu, Szmaglewska, Żywulska)}

The problem of presenting the traumatic experience of deportation and detention in a concentration camp is still painfully topical, the more so that hitherto existing methods and linguistic strategies provide no useful tools for its investigation, being either frustratingly ineffective, or altogether useless. Over time, a certain regularity in handling the problem has become noticeable, i.e. a distinctive separation of the available accounts of the experience into those provided by women and those evidenced by men. The answer to the question of how to narrate has to be then preceded by an appropriate question on social, cultural and gender identity of the narrator. On the basis of the exemplary accounts by four former inmates of the concentration camp at Auschwitz-Birkenau it is possible to understand the specificity and uniqueness of feminine perception of the camp's reality. The accounts provided by Charlotte Delbo, Liana Millu, Seweryna Szmaglewska and Krystyna Żywulska all easily identifiable by the different adopted form of message conveyance - share the specificity of women's subjects raised, aspects closely related to the structure of a woman and her existence in responding to extreme conditions, often omitted in accounts provided by male witnesses. Camp pregnancies, dramatic deliveries, pseudo-scientific experiments, rapes and prostitution - all these constitute additional themes related to by women, victims to the above.

\footnotetext{
${ }^{4 I}$ S. Szmaglewska, op.cit., s. 9.

$4^{2}$ Ch. Delbo, Żaden z nas..., s. 183.

43 K. Żywulska, op.cit., s. 310.
} 
JoAnna TeKLIK - dr, adiunkt $\mathrm{w}$ Zakładzie Komparatystyki Literackiej Instytutu Filologii Romańskiej UAM, autorka licznych artykułów publikowanych w pismach polskich, francuskich i czeskich. Zajmuje się m.in. piśmiennictwem obozowym, jego formami i gatunkami oraz problemem recepcji i literackości świadectw obozowych. Pracuje nad rozprawą habilitacyjną, która poświęcona będzie zastosowaniu krótkich form narracyjnych w świadectwach obozowych (francuskich, polskich i włoskich). e-mail: joanna.teklik@amu.edu.pl 